\title{
Shared, Shamed and Archived Images of Vulnerable Bodies: On the Nexus of Media, Feminism and Freedom of Speech in Scandinavia
}

\section{Bodil Marie Stavning Thomsen}

In recent years, the easy sharing facilities provided by social media have been much debated in Scandinavia in relation to the vulnerability of individuals whose images are shared (with or without consent) on platforms such as Facebook, Messenger, Twitter, Snapchat or other more or less closed web fora. ${ }^{l}$ While sharing between individuals is often done with consent, distributions to a wider group is generally done without consent. This vulnerability on the Internet, identified in words such as 'cyberbullying', 'hate crimes' and 'hate porn', is a real player among youngsters, who hold the opinion that freedom of speech is a democratic right in the Scandinavian welfare states, but who are not entirely familiar with the rules of ownership and copyright issues connected to older media and art forms.

B. M. S. Thomsen $(\bowtie)$

Department of Scandinavian Studies, Aarhus University, Aarhus, Denmark e-mail: bodilmarie@cc.au.dk

(C) The Author(s) 2020

A. M. Dancus et al. (eds.),

Vulnerability in Scandinavian Art and Culture, https://doi.org/10.1007/978-3-030-37382-5_4 
The task of this chapter is to take a closer look at the vulnerability involved in self-exposure on the Internet in relation to questions on women's liberation movements and the constitutional rights of free speech in Scandinavia. ${ }^{2}$ The chapter will focus on cases and discussions related to Danish culture except for the analytical exploration of the Norwegian TV series $S K A M$, which was highly popular in Denmark with 3 viewers out of 10 in 2016 (Eskesen 2016). The guiding research agenda sets off from the thesis that freedom of speech is closely intertwined with one's access to and mastery of media and, consequently, that one of the central issues of the Feminist movement in Scandinavia-whether or not one should have access to the copyright of one's own image-is central to this. Danish Feminist Emma Holten's point-that young women must have the right to give or deny consent to the circulation of their 'own image'-is included in the chapter, as well as the stance taken by her and other young Scandinavian Feminists that women's liberation has to be negotiated through the conditions of contemporary media (Dich 2017). Feminists of today demonstrate both obvious objections to sharing their images without consent, as well as affective forms of playfulness on the Internet. It is my point that the latter displays mastery of the medium, and that it is through the ability to administer and master a medium that the 'freedom of speech' is negotiated in our Scandinavian culture-today as well as in the past. To my mind, freedom of speech should, today, include not just spoken and written expression, but also the consent or non-consent of individuals whose images are exposed, shared or shamed as content; for example, becoming vulnerable body-objects. The idea of copyright may be too narrow and not easy employable in such issues, since ownership concerning images has generally been attributed to the subject of the act (the painter, the photographer) and not to the 'object' portrayed or exposed.

The crux of the matter is that the sharing of images today is done through interfaces through which the issue of ownership of content is blurred. According to Anna Munster's definition, interfaces accentuate the intensity of a folded relation between sensing your own body (from the inside) while, at the same time, mapping it (from the outside) (cf. Munster 2006, p. 142). So, simultaneous with the 'so-called' content, the involvement in a folded relation between inside and outside in the very act of chatting or image-sharing, for example, brings affect-relations to the fore. ${ }^{3}$ Thus, a traditional conception of being either the subject of ownership (or of perception), or an object of ownership (or perception) 
is blurred. The chapter will take its point of departure in a short close study of the affectively felt role of interfaces in the Norwegian TV series $S K A M$. It clearly illustrates how issues of sexual freedom and expression of individuality are closely linked to interfacial mediations of affects. These can-as will be shown - be both studied in the narrative or thematic distribution of how bodies act and relate, and as forces of affect that highlight the signaletic materiality of interface relations.

The term 'the signaletic material' that I will use throughout the chapter refers to Gilles Deleuze's definition in Cinema 2: The Time-Image (Deleuze 1989), where he underlined that the inclusion of movement (from film media and onwards to electronic media) should entail a theoretical move from sign to signal. The accent on meaning-making, representation and narration as a 'piece of information' should be switched to an interest in the medium as message, as 'source of information' (Deleuze 1989 , p. 269; cf. Thomsen 2012, 2018). In this chapter, I propose to look at real-time text messages and image messages on social media platforms as something that brace and support-for better or for worse-a folded relationship to one's own body in a folded intensity to the signaletic material of the interface. Nothing is stable in interfaces. But, as in all relations-mediated or not-we can focus on establishing what Brian Massumi terms 'a thinking-feeling of what happens' that can make us 'see potential' and 'a life dynamic, [where] we virtually live relation' (cf. Massumi 2011, p. 43). Even though it can certainly be an experience of vulnerability to share content on the Internet, it is important to notice that negotiations and fixations of meaning most often happen in social and cultural contexts. The channel for this negotiation is often the amount of 'likes' or 'sharings'; that is, the level of algorithmic data measurement that has become a new filtering mechanism in media for accessing the level of cultural meaning.

The chapter will conclude by taking a closer look at the 'immediate' level of the signaletic material and the interfacial fold that escapes classical aesthetic studies of meaning and reproduction. The 'immediation' is precisely described by Alanna Thain (in relation to cinema) as a 'suspendedness' or 'du-pli-cation, the felt folding of the world'. She continues with a characterization of David Lynch's film Inland Empire: 'This suspendedness is neither displacement nor alienation, but an infidelity to the self, understood here as the "crime of time" (Thain 2017, p. 12). Lynch famously explores this 'crime of time' in Inland Empire by making specific use of the recording facilities of video (the rewind and recording-erasing 
procedure, especially), and thus the signaletic material or the interlacement of past and future representations of a body, for example, can be immediately 'felt' in the perception of the film. The signaletic materiality is easily graspable when thinking of the grainy salt-and-pepper electronic structure of video that is also an important ingredient to affect in many of Lars von Trier's films (cf. Thomsen 2018). In the following short study of two significant episodes of SKAM, it is my intention to highlight how the interface is explored as the explicit 'content' between actors, screens and situations - thus becoming a 'felt' signaletic material to the viewer. That the series explicitly explores the idea of shame and shaming amongst youngsters (between the ages of 16 and 19) in Norwegian High Schools, where identities are vulnerable and objects to cultural negotiation, makes the series a clear-cut case for studying affect. The series can be seen as an exploration of the affective intensities of interfaces in relation to the vulnerability of youngsters who need to master not only their social and cultural identity offline, but also their online identity, which includes fashioning and controlling one's 'own image'.

\section{The Sharing of Shame in SKAM}

The Norwegian TV series SKAM (Shame) comprises four seasons with 43 episodes, written and directed by Julie Andem, and originally broadcast in Norway 2015-2017.4 Its huge success in Scandinavia was certainly due to the integration of interface screens such as mobile phones and computers in the narration. Nevertheless, this has not been studied nearly as much as the representational content; that is, the description of sexuality, ethnicity, shame, or the slang used between the youngsters (cf. Stage 2017; Christensen 2017; Hougaard et al. 2017). Whereas the studies by Anne Jerslev (2017) and Vilde Sundet (2017) also highlight the series' creation of immediacy and hypermediacy, and erasure of bounds between fiction and reality, due to the use of digital media platforms and real time, Krüger and Rustad (2017) and Rustad (2018) focus on the series as producing 'a digital space for interaction and experimentation' (Krüger and Rustad 2017). Meanwhile, the following will focus especially on the use of interfaces in SKAM, and explore the intensification of affect relations involving bodies and technology alike. In recognizing this level, it raises other, broader questions: 'What do interfaces do?'; 'What proportion do interfaces comprise in shaming or in vulnerability?' In the summary that 
follows, I have used italics to accentuate when interfaces are key to a narrational unfolding.

I will focus on season II, episodes 9, 10 and 11, where Noora as the main protagonist negotiates her relation to William, whom she dates on and off. The focus of the three episodes is whether or not William's brother, Nicolai (Nico), has doped and raped her, and afterwards shared his photo of her naked body online. This narrative thread initiates episode 9, when Noora wakes up after a party, naked and lying in the same bed as Nico and another girl, sleeping behind him. She quickly dresses, collects her purse and cell phone, and flees the scene. The following evening at her place, she searches the Internet for information on alcohol-related doping and rape in trying to figure out, why she remembers nothing about the party. She also searches for Nico's contact information and texts him asking what happened at the party. Meanwhile, she does not respond to Williams many text messages and calls on her cell phone, as well as at her door. On Monday morning, William contacts Noora at school, only to be let down again. For the entire week she checks for messages from Nico. At the end of the week, he texts her, assuring her that nothing happened at the party. Immediately after she finds William, and they reconcile with a kiss. William tells her that Nico is a psychopath who would do anything and everything to ruin their love. William has to leave straight away, and Nico texts her again saying that he now remembers how willing she was and that she acted like a whore. An image follows of her naked body in the bed. She takes a close look (as does the viewer) and freezes. In episode 10, she wakes up in her own bed, thoughtful. William texts her, wanting to spend time with her. She lies and texts back that she is sick. She texts Nico again, asking what happened last Friday. He immediately texts back, wanting to meet up with her. William enters her room and, under pressure, she tells him a white lie but a true story about her deadline for an article about Norwegian Constitution Day, 17 May. He calms her and, while she falls into a deep sleep, he writes the article for her at her computer, making sure to shut down the announcements of messages coming in. The next day, he wakes her up and drives her to her friend Eva's place to celebrate Norwegian Constitution Day with her friends. Here, Eva reads aloud Noora's (i.e. William's) article from her iPad. It connects the freedom of the welfare state of Norway with youngsters' intensive use of social media, and their constitutional rights and responsibilities to society. Her reading leaves Noora crying at the end. Confronted with the attentive care of her friends, she blurts out that Nico may have raped her. The 
group of girls forces her into action and escort her to the doctor, who examines her and views the photo on her cell phone. Two days later, she meets up with Nico at a restaurant and confronts him with the fact that producing, keeping and sharing sexualised images of children is a criminal offence in Norway, carrying sentences of up to three years in prison. She also quotes the criminal law on serving alcohol to underage persons. She points out that, according to both laws, she is considered underage or a child, and underlines the words 'without consent' ('uten mitt samtykke'). Even though cornered, he threatens her, but she leaves the restaurant, having shown him that she recorded their conversation on her cell phone. A few days later, a text message from Nico makes it clear to her that he has given William the impression that she had a one-night stand with Nico about which she remembers nothing. William furiously approaches her, as her lack of memory makes it impossible for her either to confirm or deny Nico's claim. In episode 11 , Noora finally plucks up courage to approach the girl, Mari, who shared the bed with Nico and herself after the party. Mari makes it evident that Nico did not rape her, and Noora is convinced when Mari gives her more background information about Nico and William's family. In the long reconciliation scene between William and Noora that follows, numerous text messages are exchanged back and forth and, at last, she succeeds in making William interrupt his planned flight to London. The essential information to the viewer, however, is that Noora has reported Nico to the police for having an image of her naked body in his possession without her consent.

When watching these episodes, it becomes clear how all interface screens and functions serve the purpose of bringing key messages to the fore to the TV viewer, who experiences the real-time level of online discourse as though present (cf. Jerslev 2017; Krüger and Rustad 2017; Sundet 2017). The beeping and texting sounds, as well as the close-ups of message content, function as mimetic traces to the affective level of online devices familiar to the viewer. Along with this, Noora often checks her smart phone waiting for messages that just as often arrive unexpectedly. Thus, narrational time is folded into the flow, the overload or the interrupting forces of interface sounds and images. Another level of affect is due to the fact that Noora, in the first part of the italicised interfacial situations, - before confessing to her friends - is mostly portrayed as a vulnerable body in pyjamas suffering from eating disorders. That she has stopped eating after the party is stressed several times, and this alludes to the general depiction of her as fragile and vulnerable throughout the 
series. For the key speech at the 17 May celebrations, about constitutional rights intertwined with youngster's responsibilities in relation to the time and energy used online, Noora wears a very short and slim-fitting white dress that makes her look both underaged and anorectic. On their way to the doctor's practice and to display modesty, three of the girls wear full-length national dress as typically worn by Norwegians on May 17. The group appears determined, almost revolutionary, when dragging the vulnerable Noora along in their midst. In this scene Noora presents the group as well as the doctor to Nico's apparent intimate photo of her that-without this action-might have developed into shameful online content, if shared by Nico to his friends. In the last part of the italicised situations, Noora wears normal clothing. In demonstrating to Nico that she recorded him threatening her, the series points out that, by framing him, she masters her online and offline existence.

All of the above follows a classical narrative reading of relations and actions. In the next section, I will focus on Noora's change of bodily expression from affectionately kissing William to her frozen posture at the sight of Nico's photo-which presents her as a slut-at the end of episode 9. The reason for focusing on this scene is that the felt intensity experienced with William does not correspond with Nico's interfacial sharing of her body as seen from the outside. She cannot remember and, in a sense, was 'not there'; thus, 'she' is not in the picture-neither as 'feeling' nor as 'image'. She did not take part in the interfacial folding even though she was 'there'. The result is devastating: at the beginning of episode 10, she seeks isolation, escapes her closest friends, and her line of flight is already designated: to become an anorectic body. The negative affective state she is left in, confronted with Nico's framing of her, is the reverse of the affects of joy she just experienced with William. The power to act and to extend this power to grow as a person cuts into an immediate level of sensation (including the viewers') that, on a narrative level, is closely related to Noora's paranoid or anxious handling both of text messages and of personal approaches. The episodes taken together clearly demonstrate that affects influence a body's power to act-along with its image affections and ideas - and its capabilities of becoming either joyful or sad, as explained by Deleuze in his reading of Baruch Spinoza's Ethics:

The passage to a greater perfection, or the increase of the power of acting, is called an affect, or feeling, of joy; the passage to a lesser perfection or the diminution of the power of acting is called sadness. Thus the power of 
acting varies according to external causes for the same capacity for being affected. The feeling affect (joy or sadness) follows from the image affection or idea that it presupposes (the idea of the body that agrees with ours or does not agree); and when the affect comes back upon the idea from which it follows, the joy becomes love, and the sadness, hatred. In this way the different series of affections and affects continually fulfil, but under variable conditions, the capacity for being affected. (Deleuze 1988, p. 50)

In this way, the three episodes of SKAM II dig into the vulnerability of youngsters in relation to the affective intensity of interfaces, when hindered in mastering and accessing their 'own image'. In interfaces, affect arises not only in encounters with other bodies, things or experiences. The very folding experience of interfaces includes recognition or misrecognition of (our own) images as well. So, as shown, Noora's demand for 'consent' if Nico shares a picture of her questions ideas of both ownership and copyright, as well as classical ideas of freedom of speech. When speaking from the position of the objectified, she is within her rights to ask 'whose ownership?' and 'whose freedom of speech?', since Nico's ownership of the photographic 'content' that portrays her as a slut limits her freedom of speech. As photograph and 'owner' of the copyright according to classical laws of distribution, he has the advantage of mastering her access to both the interpretation of her image and her access to its interpretation. She is not on equal terms with him.

The question of copyright to one's own image or text is also dealt with in the three episodes, if William's point of view is included. To him, the question of whether or not Noora loves him is tightly keyed to the question of whether she is trustworthy and true (to him). In other words: is she the right object of his desire, and can he 'own' her? While Noora deals with the exploration of the affects of sadness in starving, and her friends call for medical and legal assistance, William helps her by making her rest and by finishing her article before the deadline. He steps in but, due to her lie, he acts on false premises. She is not able to confess to him that Nico has diminished her power to act. To William, she has to keep her body an object of desire in order to affect joyful passions in him.

The important breakthrough of her fences-and the ability of her friends to help her out-stems from the mixed affects running through her body, when Eva unexpectedly reads her 'supposed' article. The content of the article brings together constitutional rights and responsibilities in relation to social media and the freedom of the welfare state. 
This makes her shameful in relation to William: she is both ashamed and touched by his unselfish act of writing, and thus 'falsely' giving her the copyright. The 'expressionist' side of Noora's pretence of ownership, when Eve ceremoniously reads her 'false' article, makes her shameful in another way. She has not deserved the admiration of her friends. On the level of content, what matters in her affects toward William is that she cannot return his gift of love (his renunciation of ownership) since she, herself, has no copyright to her own body-image and thus cannot access the bodily affects of joy that might give her a power to act. On the level of expression, the whole situation becomes insincere, since her power to act has been diminished. Thus, confronted with the pathetic register of the text in relation to the false copyright, she has to uncover both her friends' idea of her being a virgin and her disguised secret of being robbed of the copyright to her own (shared) image. This episode makes it clear that, on an affective level of experience, losing copyright to one's online image can be just as strongly felt as encountering bodily affects offline. This register of affect can easily be dismissed, if we only attend to the discursive level of narration. At the end, Noora takes control over the interfacial 'signaletic material' of her body-image, through which she also come to master her anorectic body and her needs. She learns how to respond to the constitutional rights and responsibilities into which both her offline body and online body are affectively enfolded. As pointed out earlier, the central expression 'without consent' is clearly presented in these three episodes as a necessary amendment to the constitutional freedom of expression as celebrated on Norwegian Constitution Day.

It is fascinating that the above episodes of SKAM concerning shaming on the Internet refer directly to the constitutional rights in the Scandinavian welfare state of Norway. With the above affect-relational reading in mind, the following section will take a closer look at the historical intertwinement of sexual liberation and freedom of speech in Denmark. I will start with a short retrospective on the time after World War II when attention was paid to both the rise of the second Feminist movement and the mediation of bodies in the public domain of pornography. 


\section{Freedom of Speech, Sexual Freedom and Vulnerable Bodies}

The postwar era in the Scandinavian welfare states is often seen as synonymous with an increase of wealth and leisure time, identified, among other ways, in modern housing, and modern furniture and design. In Denmark, democratic ideas of an equal and free way of living freed from repression were developed in the cultural radical movement 'Kulturradikalismen' of the 1920s and 1930s. ${ }^{5}$ Amongst its proponents were Otto Gelsted, Hartvig Frisch and Poul Henningsen, who were working for an emancipated culture in the fields of literature, theatre, design and architecture. Their ideas were on par with the 1930s Sex and Society movement, that (inspired by Wilhelm Reich) believed that repression and powers of war on a societal level were directly related to the individual's lack of sexual freedom (and orgasm). Therefore, they argued, women's access to abortion and contraception was key to sexual freedom and the liberation of society. In the 1950s and 1960s, this general belief had impacted both the Cultural Radicals and Danish society at large, where illegal abortions became a growing problem among young, independent women, who saw marriage as paternalistic rescue from pregnancy.

Books with pornographic content were liberated from censorship in 1967. The trial case in 1965 concerned a Danish translation of John Cleland's Fanny Hill (1748), which was later published with a foreword by Poul Henningsen. Subsequently, Denmark became the first country to allow pornographic images and films in 1969, followed by Sweden. Both nations became huge distributors of pornographic content. It is often forgotten that the free mediation of pornography in magazines and films, which often trademarked fair-haired, sexually liberated Scandinavians, was closely related to both an easy availability of the contraception pill (in 1966) and the legalisation of abortion before the 12th week of pregnancy (in Denmark in 1973). At the beginning of the 1970s, everything was ready for the young generation's sexual experimentation, followed by the second wave of Feminism's claims for equal opportunities for men and women.

The historical convergence of free distribution of sexual content and sexual liberation (from motherhood) in Denmark can, in this way, be interpreted in continuation of the struggle for freedom of speech. Today, with a hitherto unseen global scale of mediated freedom to both display 
and distribute sexual content online, it becomes imperative also to question whose freedom of speech we are protecting, if we cannot protect online body-objects from endless display or archival presence. Negotiation of 'whose body should be displayed how by whom' has become an identity-political issue globally. The mastery of online mediation, distribution and the conditions for freedom of speech (and sexuality) are a central issue to the fourth Feminist movements in Scandinavia for a reason: the vulnerability of real bodies is at stake. ${ }^{6}$ The claim, that the freedom of being creatively involved in online expressions of any kind-with consent-is key to Feminist issues. It shows that the fight for equal access to freedom of speech and alternative ways of thinking and feeling the body and its potential in body-images always has to respond to contemporary forms of mediation.

\section{Private Content and Copyright, Public Concerns and Public Service}

In Scandinavia, personal media such as smart phones are everywhere, ${ }^{7}$ and free wi-fi has almost become a human right, categorized within the same claims to infrastructural equality as access to water and electricity in public spaces. ${ }^{8}$ Our global media culture with its $24 / 7$ news feed and real-time communication has become an appreciated value as well as a problem, since the sharing of 'content' and comments, rarely allows the offended to counteract, as illustrated in the three episodes of SKAM II. It is noteworthy that so-called 'revenge-porn', where 'private' images shared between friends or lovers are later distributed to a wider audience, are often defended by the former friend or partner with reference to a 'change' in this relationship. Thus, the changed status of a relation seems also to change the status of the photograph-from being a private token of trust or love to becoming an object 'owned' by the perpetrator. This ownership justifies its being 'traded' or shared with a wider public, even though it is widely known that once something is shared online it cannot be deleted. Furthermore, the signaletic material of the Internet does indeed create immediation in the sense elucidated above by Alanna Thain (2017) — as a 'suspendedness' or 'du-pli-cation' (p. 12). So, seeing oneself as a pixelated (maybe even manipulated) image on the Internet surely can occasion feelings of suspendedness, or intensify affect reactions due to the folding operation of the interface. When shared and archived, an image or video taken without consent from the portrayed, has the risk of 
becoming a haunting object with no date of expiration-just as in Lynch's film Inland Empire. Thus, the feeling of suspendedness or du-pli-cation is strengthened in being deprived ownership to one's 'own' image.

The vulnerability of knowing that nothing can be erased becomes critical, especially to youngsters, who negotiate both identity and sexual orientation online. Joyful 'sharing' and interfacing as an intensification of affect is attractive, and even a necessary dimension of online existence, if youngsters want to be on a par with, and maybe even master, social media platforms (cf. Kofoed and Ringrose 2012). This field challenges the grey zone between 'public' and 'private', and connects to endless discussions on how, for example, images of naked bodies should be negotiated in a 'public' domain. In Denmark, the case of revenge-porn has in recent years been discussed in parliament, where more than one hearing on the subject has been held, since these assaults have violated individuals who are literally unable to defend themselves against new sharing of content. Violations in the form of cyber-bullying have especially become widespread amongst peer groups in upper secondary schools and it has become clear, on a state level, that these new forms of crime and violations of 'private' content demands a higher level of police awareness than has hitherto been offered. ${ }^{9}$

This said, it is important to stress that, even though people still use the terms 'private' and 'public' as though the boundary between them is as clear as it was in the nineteenth century, the terms should be set in inverted commas as above, since they have become almost obsolete. The sharing, the 'likes' and other emoji's should, in light of McLuhan's wellknown phrase 'the medium is the message' (introduction in McLuhan 1964), be considered the message or 'content' of contemporary media. This overall message of the media has indeed changed or overruled 'content' in the sense that, in general, our culture follows the medium as source of information (Deleuze 1989, p. 269). If a post (of content), for example on Facebook, is shared enough times, it attracts more sharing, more likes and, ultimately, the number of sharings itself will (as a so-called 'vox-pop') become a 'public concern' (and thus new content) in the news feed of TV and print media. Numbers of online likes and sharings are messages with impact on our behaviour and our values, as well as on political opinions over time. ${ }^{10}$

Besides illustrating McLuhan's point, this example also shows that realtime distribution and speed is favoured over considerations of censorship or copyright, known from the printed press with clear political stances 
shared by their readers. A conflict concerning the democratic right to 'free speech' can be traced here. Whereas the slower distribution of the printed press allowed for the censorship of offensive content in 'public' domain, Nordic television channels (DR, Denmark; NRK, Norway; and SVT, Sweden) have an obligation to bring (independent news and a wide range of original, challenging and relevant public service content that reflects the cultural and societal values of each Nordic country'. ${ }^{11}$ The point here is that citizens pay a licence fee for being informed as democratic citizens; with regard to the 'free speech' content-or, as argued above, since Internet information has become the new meaning-no one knows how copyright of 'private content' could be secured when shared, or how the messages of vox-pop could be administered or limited.

\section{The Vulnerable 'Body' Speaks Back}

As argued, global sharing of offending, fake or 'private' content (images, videos, opinions and remarks) notably affects public opinion, and is again echoed on social media. This (re)action mode rarely allows victims to counteract, since 'vulnerability' is connected to the medium-to the sharing and distribution - that becomes the message. This is the signaletic material of the Internet media that overshadows meaning in the form of signs. Therefore, cleansing the wound of the deed by removing 'content' can never remove the vulnerability (of bodies) shared online. That you are seen and victimized by others, often with delayed knowledge of this offence, is especially hard when images and videos of so-called 'private content' are shared in closed web forums, hosted in foreign countries safe from police investigation. The distribution is endless, ${ }^{12}$ and the production of value (formerly connected to a sign or a commodity) is unknown to the person whose image has become the carrier of the signaletic material. This vulnerability has been noticed by the Danish Institute for Human Rights Report. In Human Rights in Denmark: Status 2016-17 (Christoffersen et al. 2017), in the section 'Gender Equality', it says:

In 2016, revenge porn assumed a prominent place on the political agenda. The debate and subsequent cases indicate that sharing compromising photos without consent is a more widespread problem than previously assumed. A study carried out by the market research institute YouGov in 2016 for DR showed that up to four out of ten young persons between 
15 and 30 years old have sent or shared nude photos of themselves, while more than half have received a nude photo of another person. The number of police reports has grown significantly from 2011 to 2016, and the police have had difficulties investigating and prosecuting offenders, e.g. because the offenders use foreign file-sharing services. (Christoffersen et al. 2017, p. 46)

Besides this, new voices are heard in the Danish culture. Among these, is Danish feminist Emma Holten, who raised the issue of the (copy)right to one's own image. She became an activist in 2011, when she found images of her naked body exposed on the German TV channel, RTL. The channel, infamously known for its soft porn programming, had hacked the images of Holten from her e-mail and Facebook account without her consent. ${ }^{13}$ They were self-portraits sent to her boyfriend three years earlier. Her most important activist step was to amend the word 'revengeporn' to 'porn-without-consent', and to publish the project 'Consent' (Danish: 'Samtykke', cf. Holten 2017). ${ }^{14}$ In this publication, she acted as a model for photographer Cecilie Bødker. Together, they aimed to explore whether a woman's body (in this case, topless portraits) could be portrayed, freed from the 'male gaze' (cf. Mulvey 1975). Holten also discussed the fact that she, herself, had been the model as well as the photographer of the images she sent to her (former) lover as a gift. ${ }^{15}$ After the production of 'Consent', she became a global spokeswoman for online vulnerability worldwide. ${ }^{16}$ In the context of this chapter, it is noteworthy that, even though Holten generally condemns online distribution without consent, she underlines the importance of not avoiding online exposure. She supports the need, especially for youngsters, to 'perform gender' on social media.

Social media were indeed also key to the global \#Metoo manifestation of sharing experiences of sexual harassment in 2017. ${ }^{17}$ These accounts have radically changed the attitude towards vulnerability online as well as offline. For, contrary to what comprises the case of the web fora in sharing porn-without-consent, these accounts are in accordance with the quantifiable element of the Internet. They cannot be explained away simply due to their numbers, and individuals cannot be objectified and categorized since she or he is notoriously one of many. Contrary to this, the 'content' of porn-without-consent is kept in secret and obscure web groups. ${ }^{18} \mathrm{In}$ this sense, the successful action of \#Metoo and the feminist claim of freedom of speech online and offline ${ }^{19}$ has a basic likeness with the second 
Feminist wave of the 1970s. The public gathering made a difference then just as the public sharing of accounts makes a difference today-purely by the power of quantity.

\section{Constructing a Bioethical Meta-Body Online}

Notwithstanding this, questions on the ethics of self in relation to blogging, sharing and the distribution of selfies online is often debated. Inspired by Foucault, Joanna Zylinska proposes the term 'bioethics' for the necessary narcissism in 'becoming and self-creation' involved in the use of online media (Zylinska 2013). Whereas Foucault is positively interested in the auto-poetic practice connected with notebooks as both a means for recollection and memory and as a way to create a logos bioéthikos' or an ethos of life, Zylinska draws a wider conclusion of bodily becoming within networks, data and electricity:

diaries, blogs and online profiles are not just commentaries on someone's life, already lived to this point, but also somehow more 'real' outside its narrative; rather, they are materializations of it. Digital writing and linking is therefore a form not only of cultural but also of corporeal production; it literally produces the body by temporarily stabilizing it as a node in the network of forces and relations: between multiple servers and computers, flows of data, users' eyes, fingers and sensations, particles of electricity and so on. (Zylinska 2013, p. 99)

If sharing of content is seen as a bioethical production of (in)dividual bodies closely connected to online and interface technology, it becomes apparent that the Scandinavian fourth wave of Feminism is negotiating bioethical meta-bodies online. The second wave of Feminism's negotiations of the right to control one's own body in terms of sexuality, appearance and reproduction were likewise technologically embedded in the electronic hype of the day. Global connectivity was performed via electronic music, live-concerts, video-art and real-time transmissions on TV. This technological backdrop was just as substantial to the 1970s claims for new democratic forms of freedom of speech as contemporary media are today. ${ }^{20}$

The outspoken demands of visibility on the Internet put forward by women from the fourth Feminist wave should not be termed 'narcissism' in the negative sense. ${ }^{21}$ Rather, as Erinn C. Gilson indicates (Gilson 
2014 , p. 127), ethical concerns in relation to affective experiences of vulnerability should embrace that 'vulnerability is the necessary condition of creative, critical, and novel becomings' (p. 149). As already mentioned in relation to affect, becoming is key to the understanding of change. All events and affectively felt encounters (negative and positive) carry the potential of twisting, deforming or creatively changing the conditions of what Gilson (with Gilbert Simondon) terms 'collective individuation', meaning that changes in culture on individual as well as collective levels of transformation have to pass through social and technological networks of their time (cf. Gilson 2014, p. 139). The point is that the same vulnerability that, on an individual level, might affect sadness otherwise could inspire change and even joy in the perspective of collective individuation. In the above reading of $S K A M$ dealing with individual exposure to shame, it is shown that bioethical changes can happen, if encapsulated, individual affects are collectively individuated by way of a media technologic response.

The production of meta-bodies needs the operation of interfaces, as indicated by Zylinska. Returning to Anna Munster's (2006) definition of interfacing as affectively felt in the passage 'between sensing and rendering' (p. 142), alterity becomes central to bioethical becoming:

Affect arises relationally and is produced out of the difference between being in the body and representing/mapping the body from the outside. Affect sustains the singularity of sensing and of representing as a differential experience of embodiment, one in which alterity has a place. And in any interface between bodies and technology we will always encounter this difference. (Munster 2006, p. 142)

According to this, affect is experienced as micro-perceptions in the informatics of rendering, felt as 'at once strangely distant or removed and immediately intimate' (Munster 2006, p. 142) Interfaces (re)construct and deconstruct meta-bodies, and this is vulnerable per se, since we will always-like Noora in $S K A M$ - explore a certain amount of affect and alterity in the passage between feeling the body from the inside and mapping it from the outside (Munster 2006, p. 142) ${ }^{22}$ We tend to forget the interfacial micro-perceptions experienced in vibration, electric stimuli of sounds and pixels operating directly on a sensational level of perception. With Brian Massumi, those experiences could be termed 'non-sensuous 
perception' (Massumi 2011, p. 23), since we do not distinguish between body and matter:

We do not see the electrons traveling down our optic nerve. We see what our body makes of their activity. We take their activity into our own, producing an event of seeing - certainly a novelty for an electron. In the arcing of the event toward the production of its novel outcome, physical matter, life matter in general, and human life-matter are actively indistinguishable. (Massumi 2011, p. 27)

Massumi stresses that non-sensuous perception includes things that we do not see but that we nevertheless experience without knowing. This affective perception takes part in becoming, in the unfolding of future events. If our focus were more on micro-perceptions and bioethical becoming or collective individuation in the signaletic material of interfaces, the energy and joy experienced online may actually be seen and read.

\section{CONCLUSION}

This chapter has dealt with the bioethical composition of online metabodies. The questions 'What do interfaces do?' and 'What proportion do interfaces comprise in shaming or in vulnerability?' raised at the beginning of this chapter were studied through three episodes of $S K A M$. The question of shame in the series in relation to Noora's 'meta-body' was read through the theory of affect and in seeing interfaces as a folding operation of intensity between sensing and rendering. In reading the microperceptual plane of the signaletic material, it became evident that 'shame' not only signifies vulnerability in terms of social and sexual marginalisation, it also gives expression to vulnerability as connected to the bioethical affects and non-sensuous perceptions of interfaces. As such, bioethical affective events can be considered the 'name of the game' of SKAM. In all episodes, the alerts of instant messaging or the ringtones interrupt the narration and function as intervening paths or refrains to the actions or exchanges taking place. They function as distractions, as in real life, but they are also cued into an overall exploration of meta-bodily reconstruction and deconstruction of online existence. Zooming into a microperceptual level of affective involvement gives the viewer an opportunity to feel an interfacial fold-even on TV. Thus, even though freedom of speech is clearly the theme on a narrational level of content, the right 
to one's own (meta-)bodily expressions is felt as an extra-narrational signaletic material by way of affective involvement.

The double agency of playing a meta-bodily game and defending the freedom of speech has been key to the exploration of how access to and control of media has always been closely intertwined with questions on women's liberation in the Scandinavian welfare states. The chapter concludes that anyone whose image is portrayed or shared by others should give or deny consent to this. This amendment of the freedom of speech so highly valued in Scandinavia would be a first move towards giving a type of copyright protection to the object of sharing in contemporary media. A next step would be to limit the machinic access to our data. The chapter thus raises the question of how we, the users, could obstruct and prohibit our data from being used or archived for purposes of control and forms of surveillance without our consent. In continuation of this, the chapter also questions copyright as a law of ownership afforded to whomsoever possesses the content or data.

\section{Notes}

1. In the following, 'vulnerability' is used in a broad sense to characterize the exposure ensuing from becoming an (often unaware) object of shared intimate content (often, images of bodies). When a shared content reaches a wider public, such exposure is felt as a shaming of the actual physical body. Here, this exposure to vulnerability is explored in relation to the theory of affect following Brian Massumi's definition in "The Autonomy of Affect" (Massumi 2002, p. 23).

2. Sweden was the first country worldwide to introduce freedom of print in 1766, and Denmark and Norway followed in 1770. Even though often restricted during those first years and an object of dispute since then, the freedom of speech has been constitutional in Sweden since 1809, in Norway since 1814, and in Denmark since 1849. The protected right of a minority or an individual to criticize the state without repercussions (if defamation of individuals or violence is not exerted) has been an acclaimed value ever since. Recently, freedom of speech has been much debated, especially in Denmark, as a reaction to the so-called Muhammed Crisis that began in 2004, when a newspaper, Jyllands-Posten, asked a group of cartoonists to draw Muhammed. This, in order to test whether selfimposed censorship - on whether or not Muhammed could be depicted publicly — was the 'order the day' in Denmark. When one of the cartoonists portrayed Muhammed with a bomb in his turban and the prime minister refused to apologise for this, since it was subject to the freedom of 
speech of the press, it caused an intense reaction in Arab countries as well as in Denmark (cf. Stage 2011).

3. In the following, I will rely on Brian Massumi's definition of affect (Massumi 2002) that, again, refers to Gilles Deleuze's definition (in its difference from affections - one body to another) phrased as: 'affect refers to the passage from one state to another, taking into account the correlative variation of the affecting bodies' (Deleuze 1988, p. 49). He expands on Spinoza's definition: 'By affect I understand affections of the body by which the body's power of acting is increased or diminished, aided or restrained' (Spinoza 1677, III, p. 3; Deleuze 1988, p. 49). In both Spinoza and Deleuze, affects between bodies (and between bodies, things and events) can entail fast or slow transitions to other states. Thus, the term 'affect' is closely related to change as a becoming of events that virtually influences the actual.

4. SKAM was produced by NRK, the Norwegian public service TV channel, aimed at a primary group of viewers aged 15-17. Julie Andem started with researching the interests of this age group in Norway. Actors were selected among 1200 candidates with no former training, and Andem worked with the 9 main actors throughout all seasons, so that they had a voice in forming their characters and in the development of the series. The announcement of the series took place as Instagram posts fictionally created by Internet producer Mari Magnus as though by the actors. The audience could follow a Facebook or SMS chat between characters as well, and thus the announcement was shared by youngsters themselves-as in a relation between friends. Each episode premiered online, and ongoing feedback was likewise received on social media. After each premiere, episodes were broadcast on TV.

5. This movement must again be seen in continuation of the 1890's modern breakthrough in literature and art in Scandinavia. In Denmark, Georg Brandes was the gatekeeper of this international orientation, which deliberately kept women writers and artists back (cf. Dahlerup 1983). However, Thit Jensen's radical claims for women's access to contraception as intertwined with liberation (and unburdened motherhood) must be remembered.

6. The Feminist movement is often described as coming in waves, the first wave (USA from 1848, UK in the 1850s, Germany and Scandinavia in the 1870s) fought for equal rights and culminated in the right to vote for women. The second wave (the 1970s in the western world) fought against stereotypical roles in society and for women's right to their own bodies; the right to abortion; and the right to women's conditions of life represented in culture, art, and (his)tory. The third wave (in the 1990s) was concerned with the differentiation and the performance of gender in society, a main concern being how women's rights—regardless of religion, 
nationality, colour and sexual orientation-were still structurally restrained by patriarchy. The fourth wave (from the 2010s) is especially concerned with the bullying and harassment of women in the so-called 'slutshaming' and 'revenge porn' on the Internet. The global manifestation of women's unequal conditions in professional contexts had a huge manifestation in \#Metoo in 2017 and, in this sense, the fourth wave is still vibrant worldwide today.

7. Smart phones were marketed by Apple in January 2007 and, in October 2008, Apple had sold 4.7 million iPhones, which amounts to $13 \%$ of the global market. As early as 2008 in Denmark, 99\% of teenagers between 16 and 19 years, 98\% of adults between 20 and 39 years, 94\% of adults between 40 and 59 , and $82 \%$ of adults between 60 and 74 years used mobile phones for private communication (cf. Helles 2009, p. 84). After Apple's launch of iPads in January 2010, the percentage of other uses of screened communication has probably increased (cf. https://www.thegua rdian.com/technology/2012/jan/24/smartphones-timeline).

8. According to EU kids online, Denmark is one of the leading countries when it comes to time spent on online media by children aged 9-16, since free access is the norm (cf. http://www.lse.ac.uk/media-and-comm unications/research/research-projects/eu-kids-online).

9. In September 2018, a suspended sentence of 40 days handed down to a 20-year old boy sharing a sex video in which a 15-year-old girl had intercourse with several 15-year-old boys was sent to trial at the highest court in Denmark. This case is only one of those in the so-called 'Umbrella-case', which related to a case from 2015 in which more than 1000 youngsters had shared this video that, in some cases, had been edited so that one could not identify the girl as sexually underage. The problem is that, if the girl's face is visible, the court has to pass sentence on this case as a case of paedophilia.

10. Recently, the Cambridge Analytica scandal, where 87 million Facebook users' data were used in political campaigns and 'fake news' by way of socalled 'micro-targeting' and 'psychographic analysis' has made the public become more aware of algorithmic traces and measuring. Unable to access our own data, we are contributing to big data assemblages that can be measured, analysed and traded. Our 'likes' draw graphs or direct imprints to inform our individual (cf. Deleuze 1992) 'personality styles', and even changes in style can be followed over time.

11. Citation from the Nordic Council of Ministers, 2015: https://danskeme dier.dk/marked-og-okonomi/nordiske-ministre-vil-fremtidssikre-public-se rvice/ (accessed 12 September 2018).

12. The Danish Facebook group Offentimentum is an example of a closed forum with the purpose of distributing offensive material-and this very 
criterion seems to exceed the threshold of what is offensive. The physical harassment and bullying that one could often find in a classroom has, so to speak, moved to a virtual classroom. Due to a coordinated harassment, the site was closed by Facebook on the 11 September 2017, only to be reopened in another version 24 hours later. Before its closure, the site had 105,000 members (cf. https://www.skivefolkeblad.dk/articl e/20170912/RITZAUINDLAND/309129892) (accessed 12 September 2018).

13. Later, in 2016, she received compensation from RTL for the lack of consent on her part. Since the hacking happened much later, the case underscored that violation can happen at all times in the sharing process.

14. It contained an article and a catalogue, and was published in the feminist magazine Friktion, 1 September 2014, edited by Emma Holten (a section can be read here: https://friktionmagasin.dk/samtykke-14841780be52) (accessed 13 May 2019).

15. Her method, in this sense, mirrors the method of American photo artist Cindy Sherman, who acts as both model and photographer in order to underline the composed and objectifying operations of photographs and photography. With smart phones, this method is now available to anyone.

16. Cf. The Guardian, TED talks and so on. On 12 November 2017, Emma Holten announced her withdrawal from public exposure in the Danish television show, 'Vi ses hos Clement', DR2.

17. The hashtag was initiated by Tarana Burk in 2010 and got a major impact when singer and actor Alyssa Milano made an act of sexual harassment public on Twitter in October 2017, following the charges made against Harvey Weinstein.

18. The latter mentioned practice is in line with patriarchal traditions of menexchanging-women in order to sustain power (over women). In this practice, women are reduced to tokens of value; for example, the meaning of beauty.

19. In an interview, Holten mentioned the importance of the Internet for her generation of feminists, especially because of the ability to share experiences with other women (Kaasgaard 2016).

20. In this line of reasoning, the formation of democracy in western societies followed the rise of the printing press and new readers, who read papers and novels in their native language. Thus, once locally distributed newspapers were established according to the political parties representing farmers and workers, democracy flourished-and, eventually, also women and servants were allowed to vote. The right for women to be nominated and to vote at elections was decided in Denmark in 1915. In Finland, this right was obtained in 1906; in Norway, in 1913; Swedish women had to wait till 1919-1921. 
21. Nonetheless, some Danish feminists of this older generation have widely attacked the new feminist movement of being too narcissistic and of accentuating the female (often part-naked) body too much in public spaces. As a reaction to one of these-Mette Fugl's attack-some of the new feminists responded that they want to fight for the ownership of their own body, which also includes taking ownership of their beauty-power (cf. http://politiken.dk/debat/debatindlaeg/art5780289/Derfor-er-vi-af $\mathrm{kl} \% \mathrm{C} 3 \%$ A6dte).

22. In an article on the built-in operation of 'slutting' individuals on Web 2.0, Wendy Chun and Sarah Friedland (2015) argue that the Internet is promiscuous, and that this vulnerability should be embraced.

\section{REFERENCES}

Christensen, C. L. (2017). Er web- og tv-serien SKAM en serie om skam? Nordisk Tidsskrift for Informationsvidenskab Og Kulturformidling, 6(2), 7-12.

Christoffersen, J., Holck, L., Dyrborg, U., Emil Kiørboe, E., \& Christoffer Badse, C. (Eds.). (2017). Human Rights in Denmark: Status 2016-17. Copenhagen: The Danish Institute for Human Rights. https://www.humanr ights.dk/sites/humanrights.dk/files/media/dokumenter/udgivelser/status / dihr_status_2016-17_uk.pdf. Accessed 12 September 2017.

Chun, W. H. K., \& Friedland, S. (2015). Habits of leaking: Of sluts and network cards. Differences: A Journal of Feminist Cultural Studies, 26(2), 1-28.

Dahlerup, P. (1983). Det moderne gennembruds kvinder. København: Gyldendal. Deleuze, G. (1988). Spinoza: Practical Philosophy. San Francisco: City Light Books.

Deleuze, G. (1989). Cinema 2: The Time-Image. Minneapolis: University of Minnesota Press.

Deleuze, G. (1992). Postscript on the societies of control. October, 59(Winter), 3-7.

Dich, K. (2017, October 17). Ny nordisk feminisme. Hvordan har feminismen det i Skandinavien i dag? Vagant. http://www.vagant.no/ny-nordisk-femin isme/. Accessed 12 September 2018.

Eskesen, A. H. (2016, October 20). Knap 3 ud af 10 'Skam'-seere er fra Danmark. DR. https://www.dr.dk/nyheder/kultur/knap-3-ud-af-10-skamseere-er-fra-danmark. Accessed 12 November 2018.

Gilson, E. C. (2014). The Ethics of Vulnerability: A Feminist Analysis of Social Life and Practice. New York and London: Routledge.

Helles, R. (2009). Personlige medier $i$ hverdagslivet (Doctoral dissertation). København: Det humanistiske Fakultet, Københavns Universitet. 
Holten, E. (2017, September 1). Samtykke. Friktion Magasin for køn, krop og kultur. https://friktionmagasin.dk/samtykke-14841780be52. Accessed 12 November 2018.

Hougaard, T. T., Andersen, E. M., \& Rathje, M. (2017). SKAM-i sproget og i interaktionen. Dansk Noter, 3. Afdeling for Nordisk, Institut for kommunikation og kultur, Aarhus Universitet.

Jerslev, A. (2017). SKAMs 'lige her' og 'lige nu': om SKAM og nærvær. Nordisk Tidsskrift for Informationsvidenskab Og Kulturformidling, 6(2), 75-81.

Kaasgaard, S. (2016, May 2). Emma Holten om hævnporno: 'Jeg har fundet mig i alt for meget pis'. Eurowoman. https://www.alt.dk/artikler/emma-ho lten-jeg-har-fundet-mig-i-alt-for-meget-pis. Accessed 12 November 2018.

Kofoed, J., \& Ringrose, J. (2012). Travelling and sticky affects: Exploring teens and sexualized cyberbullying through a Butlerian-Deleuzian-Guattarian lens. Discourse: Studies in the Cultural Politics of Education, 33(1), 5-20.

Krüger, S., \& Rustad, G. C. (2017). Coping with shame in a media-saturated society: Norwegian web-series Skam as transitional object. Television and New Media, 20(1), 72-95.

Massumi, B. (2002). Parables for the Virtual: Movement, Affect, Sensation. Durham and London: Duke University Press.

Massumi, B. (2011). Semblance and Event: Activist Philosophy and the Occurrent Arts. Cambridge, MA, and London, UK: MIT Press.

McLuhan, M. (1964). Understanding Media: The Extensions of Man. New York: Mentor.

Mulvey, L. (1975). Visual pleasure and narrative cinema. Screen, 16(3), 6-18.

Munster, A. (2006). Materializing New Media: Embodiment in Information Aesthetics. Hanover and London: University Press of New England.

Rustad, G. C. (2018). Skam (NRK, 2015-2017) and the rhythms of reception. Critical Studies in Television: The International Journal of Television Studies, 13(4), 505-509.

Spinoza, B. (2010 [1677]). Ethics. Hertfordshire: Wordsworth Editions.

Stage, C. (2011). Tegningekrisen-som mediebegivenhed og danskbedskamp. Aarhus: Aarhus Universitetsforlag.

Stage, C. (2017). Om skammen i Skam-og de eksistentielle medier. Dansk Noter, 3. Afdeling for Nordisk, Institut for kommunikation og kultur, Aarhus Universitet.

Sundet, V. S. (2017). Det er bare du som kan føle det du føler-emosjonell investering og engasjement i nettdramaet SKAM. 16:9. Filmtidsskrift. Aarhus.

Thain, A. (2017). Bodies in Suspense: Time and Affect in Cinema. Minneapolis: University of Minnesota Press.

Thomsen, B. M. S. (2012). Signaletic, haptic and real-time material. Journal of Aesthetics and Culture, 4(1). https://www.tandfonline.com/doi/full/10. $3402 /$ jac.v4i0.18148. 
Thomsen, B. M. S. (2018). Lars Von Trier's Renewal of Film 1984-2014: Signal, Pixel, Diagram. Aarhus: Aarhus University Press.

Zylinska, J. (2013). The culture of blogging: At the crossroads of narcissism and ethics. In N. Couldry, M. Madianou, \& A. Pinchevski (Eds.), Ethics of Media (pp. 91-105). Basingstoke, UK, and New York: Palgrave Macmillan.

Open Access This chapter is licensed under the terms of the Creative Commons Attribution 4.0 International License (http://creativecommons.org/licenses/by $/ 4.0 /)$, which permits use, sharing, adaptation, distribution and reproduction in any medium or format, as long as you give appropriate credit to the original author(s) and the source, provide a link to the Creative Commons license and indicate if changes were made.

The images or other third party material in this chapter are included in the chapter's Creative Commons license, unless indicated otherwise in a credit line to the material. If material is not included in the chapter's Creative Commons license and your intended use is not permitted by statutory regulation or exceeds the permitted use, you will need to obtain permission directly from the copyright holder.

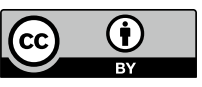

